\title{
The Mechanisms of Spatial Mismatch
}

\author{
Laurent Gobillon, Harris Selod and Yves Zenou
}

[Paper first received, October 2005; in final form, January 2007]

\begin{abstract}
Summary. The spatial mismatch hypothesis (SMH) argues that low-skilled minorities residing in US inner cities experience poor labour market outcomes because they are disconnected from suburban job opportunities. This assumption gave rise to an abundant empirical literature, which is rather supportive of the SMH. Surprisingly, it is only recently that theoretical models have emerged, which probably explains why the mechanisms of spatial mismatch have long remained unclear and not properly tested. This article presents relevant facts, reviews the theoretical models of spatial mismatch, confronts their predictions with available empirical results and indicates which mechanisms deserve further empirical tests.
\end{abstract}

\section{Introduction}

In the mid 1960s, riots broke out in the Black neighbourhoods of several major US cities (in Los Angeles in 1965, in Chicago in 1966 and in Newark in 1967). In 1968, the Kerner commission, which investigated the causes of these riots, emphasised the frustration of Black inner-city residents confronted with high unemployment rates and poor access to public services. In a seminal paper, Kain (1968) argued that a major source accounting for the adverse labour market outcomes of Blacks in US cities was to be found in the spatial disconnection between inner-city ghettos (where Blacks resided) and the suburbs (where low-skilled jobs had already begun to decentralise) (for more details on the legacy of Kain, see Kain, 2004; and Glaeser et al., 2004). This argument, which came down in the literature as the spatial mismatch hypothesis (SMH hereafter) inspired an abundant research literature over the following decades. In the 1980s and 1990s, the interest in the SMH was revived by two sociologists, Kasarda (1985, 1988, 1989) and Wilson (1987, 1996) who showed the existence of a Black 'underclass' in inner-city ghettos and attributed the endemic problems of that underclass to the sharp decrease in the number of entry-level jobs located in inner cities.

Following Kain's intuition, numerous empirical works have tried to test the existence of a causal link between the spatial disconnection from jobs and the adverse labour market outcomes of minorities (see the empirical surveys of Jencks and Mayer, 1990; Holzer, 1991; Kain, 1992; Wheeler, 1993; Ihlanfeldt and Sjoquist, 1998). The usual approach relates a measure of labour market outcomes, typically employment or 
earnings, to a measure of physical job accessibility, typically some index that captures the distance between residences and job locations. The weight of the evidence suggests that distance to jobs is indeed partly responsible for the adverse labour market outcomes experienced by ethnic minorities residing in central cities. ${ }^{1}$

It should be clearly said that the standard $\mathrm{SMH}$ focuses on a specific issue: the bad labour market outcomes (high unemployment and low wages) of low-skilled Black innercity residents who are disconnected from suburban job opportunities. The SMH considers that (inner-city) Blacks do not reside close to (suburban) jobs because they are racially discriminated against in the (suburban) housing market. Although most of the literature focuses on Black workers, the analysis is presently extending to other US minority workers, especially Hispanics who also face a significant degree of disconnection from jobs (Raphael and Stoll, 2002) even though they are more suburbanised than Blacks (Logan, 2001). ${ }^{2}$ Furthermore, the SMH focuses exclusively on the unskilled labour force: it is only concerned with the way lowskilled minority workers residing in inner cities are affected by distant job locations. This is why some authors prefer the expression spatial/skill mismatch to depict more accurately the spatial disconnection between the residential locations of inner-city minorities and the locations of the low-skilled suburban jobs they could occupy (see Ong and Blumenberg, 1998; Immergluck, 1998).

Urban economists are divided on the magnitude of spatial mismatch as an explanation of racial unemployment disparities (see Ihlanfeldt, 2006). ${ }^{3}$ However, what is very unusual and certainly contributed to the empirical controversy, is that it was only in the late 1990si.e. following three decades of empirical tests and changes in the structure of US cities - that theoretical models of spatial mismatch began to emerge. Most of the theoretical corpus associated with spatial mismatch followed the empirical works rather than preceded them. In this rather odd context, the general objective of the present work is to shed light on spatial mismatch by presenting the recent theoretical advances and confronting them with relevant empirical evidence from previous studies. We show that some mechanisms of spatial mismatch have already been addressed, while others remain to be tested. This work is carried out with a view to designing future relevant empirical tests that would investigate the different channels whereby distance to jobs can be harmful for ethnic minorities. We discuss the specific policy implications of each type of mechanism and argue that it is important to distinguish empirically which mechanisms prevail in order to design well-targeted and efficient economic policies.

Our work is organised as follows. In section 2 , we present the main ingredients of spatial mismatch: the disconnection of Black central-city residents from suburban job opportunities and their adverse labour market outcomes. In section 3, we expose the specific theoretical mechanisms that explain how spatial mismatch can exacerbate the unemployment and low wages of central-city Blacks. The empirical evidence supporting the mechanisms is also discussed. Finally, section 4 discusses the specific policy implications of the different mechanisms.

\section{Blacks' Disconnection from Jobs and their Adverse Labour Market Outcomes}

Over the second half of the 20th century, dramatic changes occurred in US metropolitan areas. The concentration of jobs continuously decreased in central cities and increased in the suburbs. Whites continuously decentralised to suburban residential areas over the same period, while many Black households remained in central cities. The combination of these trends is said to have created a situation of spatial mismatch to the extent that Blacks are now located far away from suitable suburban job opportunities. In this section, we simultaneously present some elements of theory that can account for these trends and a selection of empirical facts which shed light on their intensities. We then provide figures which characterise the adverse 
labour market outcomes of Black inner-city residents.

\subsection{The Suburbanisation of Jobs}

One of the most striking features of the American urban landscape is the massive and continuous suburbanisation of both people and jobs that occurred in the second half of the 20th century. In the 19th century, US cities were characterised by a small and dense central business district located close to an interurban transport node (typically a port or a train station). Due to high intraurban transport costs for both people and goods, residences were located near or even within that central area (Mieszkowski and Mills, 1993). The emergence of new transport modes such as tramways, trains, then cars, made it possible for the population to suburbanise. The decrease in intraurban costs associated with transport innovations enabled people to move to the suburbs in order to consume more housing while keeping their jobs at the city centre. The general increase in population and wealth also contributed to the spatial expansion of cities and fostered the emergence of rich suburban areas, especially in the second half of the 20th century. Suburbanisation remained steady during the last three decades of the 20th century, so that the proportion of central-city residents in the 10 largest MSAs had declined from 53 per cent in 1970 to 42 per cent in $2000 .{ }^{4}$ It has been estimated that, today, the median resident in a US metropolitan area lives farther than nine miles away from the city centre (Glaeser and Kahn, 2001).

In turn, the suburbanisation of the labour force continuously attracted jobs to the periphery of US cities (Steinnes, 1977; Thurston and Yezer, 1994; White, 1999). Yet other causes also contributed to the decision of firms to settle in or to relocate to the suburbs. Anas et al. (1998) mention the agglomeration forces played by local externalities as the proximity between some agents may improve the input-output linkage by reducing intermediate goods transport costs, foster innovation through technological spillovers or even reduce production costs. In this context, firms tended to relocate close to other firms in the suburbs, triggering a cumulative process of aggregation. Dispersion forces away from the Central Business District (CBD) probably also contributed to job suburbanisation in several ways. In particular, the spatial proximity between CBD firms could have intensified competition for the local labour force and for local market shares, driving firms away to more peripheral locations (Fujita and Thisse, 2002). Other significant dispersion forces accounting for the suburbanisation of jobs may have involved rising land prices, congestion and crime. ${ }^{5}$

A few theoretical models shed light on the process of job suburbanisation. When choosing their location, firms are confronted with both centrifugal and centripetal forces so that their locations within the city result from a trade-off between the advantages and disadvantages of proximity to and distance from the city centre. To model this, Fujita et al. (1997) adopt a monocentric urban framework (all jobs being located at the city centre) and consider a linear city in which workers are uniformly distributed along the segment. In their framework, a new firm wishes to settle in the city and chooses its location, but the location decision interacts with the wage policy of other firms which are already settled in the city centre. Thus, the firm faces a trade-off between proximity to the city centre and distance from the city centre (in order to increase its market power on the labour force). Using similar market power arguments, other authors have explained the emergence of secondary employment centres or edge cities (see Henderson and Mitra, 1996, for a formal model; and Garreau, 1991; Giuliano and Small, 1991; McMillen and McDonald, 1998; Anas et al., 1998; and Cervero et al., 2002, for the empirical identification of sub-centres).

It is useful to describe the extent of suburbanisation in US cities over the second half of the 20th century with the help of selected descriptive statistics. It is striking that, whereas in 1950, central cities gathered nearly 70 per cent of MSA jobs, the figure 
went down to 50 per cent in 1980 (Mills and Lubuele, 1997). Our own calculations show that, in the 10 largest MSAs, the proportion of jobs located in central cities decreased from 57 per cent in 1980 to 51 per cent in 1990 and 47 per cent in 2000. If we exclude the case of New York City which remains very centralised, the average proportion of central-city jobs for the 9 remaining MSAs goes down from 49 per cent in 1980 to only 44 per cent in 1990 and 40 per cent in 2000. This steady decrease in the percentage of jobs located in central cities can most probably be explained by a higher growth rate of jobs in the suburbs than in the central city. In the 10 largest MSAs, between 1980 and 1990 , the number of jobs increased on average by +3 per cent each year in the suburbs, but only grew by +0.8 per cent in central cities. Between 1990 and 2000, the number of jobs increased on average by +1.4 per cent each year in the suburbs, but slightly decreased by -0.1 per cent in central cities.

It should be noted that the degree of suburbanisation varies with job types. Underpinning the SMH is the observation that entrylevel jobs grew in the suburbs and declined in city centres where low-skilled minorities remain located. A theoretical argument involving the pool of consumers for low-skilled services in rich residential suburban areas can explain why this occurred. Another justification is that firms which hire low-skilled workers (especially in the manufacturing industry) consume much land and want to avoid central locations where land is scarce and expensive. The latter mechanism is central in Smith and Zenou (1997) who investigate the location of jobs in a dual labour market framework. The authors develop a model in which there are two types of job that differ by their quality (high vs low). The high-quality jobs (primary sector) are assumed to be located in the city centre. The low-quality jobs (secondary sector) are offered by a large representative firm that needs to choose its location in the metropolitan area. There are exogenous agglomeration forces that attract the firm towards the city centre, whereas land rents endogenously decrease with distance and thus play the role of a dispersion force. The chosen location results from the confrontation of these two opposite forces. When the dispersion force is sufficiently strong, the firm (and thus entrylevel jobs) locates in the suburbs.

Empirically, it is relevant to focus on manual and services jobs, which concentrate most entry-level positions. ${ }^{6}$ In conformity with the theory, between 1980 and 1990, manual jobs decreased in almost all city centres of the 10 largest MSAs (at an average annual rate of -1.7 per cent) and grew in the suburbs (at a rate of +1.2 per cent). Between 1990 and 2000, these trends continued with a decrease of -1.6 per cent in city centres and an increase of +0.3 per cent in suburbs. Services jobs, which group both skilled and unskilled positions, grew in the city centre $(+2.4$ per cent for $1980-90$ and +0.7 per cent for 1990-2000) but much more in the suburbs $(+4.1$ per cent for 1980-90 and +2.6 per cent for 1990-2000).

In a spatial mismatch perspective, these figures should be compared with the growth rates of unskilled residents in city centres and in the suburbs. The number of manual workers residing in central cities decreased continuously between 1980 and 2000 by an average annual rate of -1.5 per cent, which is slightly less than the decrease in the number of manual jobs in the same locations. In contrast, in the suburbs, the number of manual workers increased very slightly by +0.1 per cent on average each year between 1980 and 2000, whereas the number of manual jobs increased strongly. It should be clear that there are still suitable jobs for lesseducated workers in city centres (see Shen, 2001, for Boston) but the figures presented here point at changes detrimental to unskilled residents in central cities.

\subsection{The Disconnection of Blacks from Jobs}

The main assumption in the $\mathrm{SMH}$ is that Blacks mainly remained in the city centres of US MSAs in spite of suburbanisation. ${ }^{7}$ Statistics strongly support this assertion. In 2000, 
in the 10 largest MSAs, 64 per cent of all urban Blacks lived in a central city in comparison with 28 per cent of the White urban population and Blacks accounted for 27 per cent of all central-city residents but only for 11 per cent of the suburban population. Although there are strong variations in these figures when computed for specific MSAs, the picture remains one of intense Black centralisation and Black concentration in the city centres of large MSAs. In Detroit, for instance, a highly segregated metropolitan area, 70 per cent of inner-city residents are Blacks, whereas Blacks only account for 6 per cent of the suburban population. At the other end of the spectrum, in Washington, Blacks still account for 44 per cent of innercity residents and only 19 per cent of suburban residents. Of course, this asymmetry goes along with a high level of Black-White residential segregation, a prevalent phenomenon in the US. According to Cutler et al. (1999), the average Black-White dissimilarity index in US cities stood at 66 per cent in $1990 .^{8}$ Although segregation appears to have declined slightly over the past decade, it remains high: the Black-White dissimilarity index in 2000 ranged between 54 per cent for Dallas and 78 per cent for Chicago (Glaeser and Vidgor, 2001).

The persistence of segregation goes along with a high degree of residential inertia for Blacks. This is captured by Bogart (1998) who provides estimates of the average transition probabilities between neighbourhoods with different economic profiles for poor families with children. Over the 1979-84 period (for which the transition probabilities are computed), it appears that a Black household with children living in a low-income neighbourhood only had a 9 per cent chance to be living in a better neighbourhood the following year, whereas for Whites, this probability was above 20 per cent. Thus, Blacks living in poor areas are less spatially and socially mobile than Whites residing in poor areas. This suggests that it is more difficult for Blacks than for Whites to escape innercity residences. This is supported by another study which shows that Blacks have a lower probability than Whites to move from central city to suburbs, but a higher probability to move from suburbs to central city, even after controlling for socioeconomic characteristics (South and Crowder, 1997).

The causes of segregation and the residential inertia of Blacks in US cities are diverse. The first set of explanations, in line with the $\mathrm{SMH}$, revolves around restrictions imposed on the residential choices of Blacks. In this respect, housing market discrimination has been shown to play a central role in the segregation of Blacks, as evidenced by real estate agents who propose Black customers make fewer visits than White customers (Yinger, 1986). Such a discriminating behaviour finds two direct explanations: sheer racial discrimination (Becker, 1971) where suburban homeowners do not wish to sell or rent to Blacks; and, customer discrimination where real estate agents want to avoid Blacks settling in neighbourhoods that they think would then become less attractive for their White customers (see Ondrich et al., 2001). Housing market discrimination can also be accounted for by statistical discrimination in the context of imperfect information (Phelps, 1972; Aigner and Cain, 1977) where Blacks are perceived, on average, as bearing a higher default risk. Another form of discrimination is redlining where individuals living in minority neighbourhoods - as if circled by a red line-are discriminated against (see Tootell, 1996), which may stem from sheer or statistical discrimination motives. It is worth mentioning that housing market discrimination not only concerns the screening of housing units, but can also take the form of credit, mortgage and insurance discrimination (Yinger, 1996; Tootell, 1996; Ladd, 1998; Hillier, 2003; Ross and Tootell, 2004; Ross, 2005). Finally, some indirect restrictions on the residential choice of Black families may take the form of institutional regulations on land use such as zoning requirements that impose minimum lot sizes in order to prevent low-income minorities from settling in White suburban areas (Squires, 1996). Housing policies may also distort the set of location choices for Blacks 
when housing projects are only concentrated in the city centre (Kain, 1992).

The second set of explanations for the segregation of Blacks runs contrary to the standard SMH since it presents segregation as market-driven. In this context, an important driving-force of segregation can be that individuals have racial preferences that lead to the spatial separation of ethnic groups, as modelled in a series of theoretical works in the 1970s (see Schelling, 1969; RoseAckerman, 1975; Yinger, 1976; Courant and Yinger, 1977; and more recently Selod and Zenou, 2006). In the empirical literature, this is illustrated by the White flight phenomenon according to which Whites flee from racially mixed neighbourhoods when the proportion of minorities reaches a tilting-point (see Galster, 1990 and 2000). Also, minorities may self-segregate because they have preferences to reside close to individuals of their own group, as shown empirically by Ihlanfeldt and Scafidi (2002). Other segregating forces are the existence of negative externalities from the poor towards the rich or from the uneducated towards the educated, which fuel the flight out of those neighbourhoods (as in Benabou, 1993). In addition, Whites and Blacks may have different preferences for the provision of public goods which may produce spatial sorting à la Tiebout across local communities (Anas et al., 1998). Finally, Blacks may have a higher willingness to pay for housing units characterised by some specific attributes that differ from those valued by Whites. Some spatial sorting consistent with the SMH occurs if these units are mainly located in the central city.

As Blacks are highly concentrated in city centres whereas jobs have suburbanised, there exists a spatial disconnection between Blacks and jobs. Using a dissimilarity index between the residences of Blacks and job locations, Martin (2001a) estimates that the disconnection increased by more than 20 per cent over the 1970-90 period, the reason being that Blacks suburbanised at a lower pace than jobs. Since 1990, however, the disconnection from jobs has declined, not only when the Black residential locations are compared with that of all jobs, but also when they are compared with the location of retail jobs that may better fit low-skilled workers. In 2000, the dissimilarity indexes between the residences of Blacks and jobs and between the residences of Blacks and retail jobs were both close to 55 per cent (Raphael and Stoll, 2002). ${ }^{9}$ It should be kept in mind, however, that these features are average trends and that American cities present a wide range of configurations (see Pugh, 1998; or Glaeser and Kahn, 2001, for city categorisations). Ihlanfeldt and Sjoquist (1998) argue that the disconnection of Blacks from jobs is prevalent mainly in big MSAs. Using Raphael and Stoll's index of spatial mismatch between residences and retail jobs, we have checked that this assertion is supported by the data. Indeed, in 2000, the correlation between MSA size and the spatial mismatch index for retail jobs and Blacks is 0.37 , whereas for Whites the correlation is only 0.03 .

\subsection{The Adverse Labour Market Outcomes of Blacks}

Many Blacks reside in city centres, whereas jobs have suburbanised. They thus face three alternatives in the labour market: holding a job in a suburban area far away from where they live; holding a (possibly inadequate) job in the city centre close to their place of residence; and, being unemployed. Bearing these alternatives in mind, we present empirical facts concerning the commuting patterns, access to jobs, unemployment and wages of inner-city Blacks.

Average figures on commuting patterns capture two different phenomena: the long commutes of those who work in the suburbs and the short commutes of those who work in the city centre. In 1995, White and Black commutes in the US lasted on average 23 minutes. However, in terms of distance, White workers commuted on average 11.9 miles whereas Black workers only commuted 10.5 miles (computed from McGuckin, 2000, tables 4-8, 4-15 and 4-16, using the Nationwide Personal Transport Survey). 
A different source shows that the average travel time to work in the US in 1990 was 24 minutes for Blacks but only 20 minutes for Whites (Krovi and Barnes, 2000, using the PUMS B sample). Taylor and Ong (1995) provide figures by type of neighbourhood for 1985 which confirm this result. In predominantly White neighbourhoods, both Black and White workers commuted more than 11 miles and over 22 minutes. In predominantly minority areas, both Black and White workers commuted about 9 miles, but the commute time of Blacks (26 minutes) was significantly longer than that of Whites (21 minutes). The difference can be explained by the lower access to automobiles for innercity Blacks, which makes them resort to slower transport modes. In 1990, whereas 8.7 per cent of White households did not have a car, this percentage reached 30.4 per cent for Black households (McGuckin, 2000). In 1995, whereas 2 per cent of White workers' commutes were by public transit (by bus or by rail), this percentage stood at 12 per cent for Black workers. Similarly, Black workers resorted more to car pooling (20 per cent of their trips) than White workers (14 per cent of their trips) who massively used their private vehicle to commute.

A striking pattern is that access to suburban vacancies is particularly poor for inner-city Blacks. To show this, Stoll et al. (2000) compare the distribution of people and of recently filled jobs for a pooled sample of MSAs (Atlanta, Boston, Detroit, Los Angeles) in the early 1990s. In their study, whereas Blacks were overrepresented in central cities, recently filled jobs were mainly located in the suburbs. This pattern was even more striking for the less-educated and the jobs they might have occupied. While 76.3 per cent of Black high-school dropouts (low-skilled workers) lived in central cities, the suburbs gathered 79.6 per cent of recently filled low-skilled jobs. In contrast, the proportion of White high-school dropouts residing in the suburbs (77.9 per cent) was close to that of the recently filled low-skilled jobs located there.
Unemployment figures also show the disadvantage of Blacks in central cities. Brueckner and Zenou (2003) report that, in the 25 largest MSAs, the 1997 unemployment rate of innercity Blacks was 12.5 per cent, which was 5 percentage points above the unemployment rate of suburban Blacks in the same MSAs (standing at 7.6 per cent) and more than three times the unemployment rate of suburban Whites (at a low 3.7 per cent). Interestingly, the contrast between central cities and suburbs was much dampened for Whites since the unemployment rate of central-city Whites (5.5 per cent) was only 1.8 points above the unemployment rate of suburban Whites.

There also appear to be stark disparities concerning the distribution of income across places and racial groups in US cities. Mills and Lubuele (1997) report that the 1990 average income of a central-city Black was close to $\$ 8700$, which was little less than half the average income of a central-city White. Suburban Blacks had an average percapita income of $\$ 11000$, which was onethird lower than that of suburban Whites but 25 per cent higher than that of central-city Blacks. These income differences are likely to be explained not only by human capital differences but because Blacks usually work in places where wages are very low. In a study on Atlanta, Ihlanfeldt and Young (1994) find that the wage rate for employees of fast-food restaurants increased about 1 per cent per mile when moving outwards from the CBD where Blacks are more likely to work. The existence of a positive wage gradient is further confirmed by Ihlanfeldt (1997) who reports that the hourly hiring wage in a fast-food restaurant was $\$ 4.39$ in the northern suburbs of Atlanta, but only $\$ 3.84$ in the city centre. ${ }^{10}$

Consistently, the poverty rate is always higher in central cities than in the suburbs and is usually three to four times higher for Blacks than for Whites. In 1996, whereas only 30 per cent of the US urban population resided in a central city, central cities contained more than half the poor families (US Bureau of the Census, 1997) and 72 per cent of the inner-city poor were ethnic minorities (US Department of Housing and Urban 
Development, 1998). In 1990, 31.1 per cent of Blacks living in central cities were poor whereas the poverty rate of central-city Whites stood at only 12 per cent (Mills and Lubuele, 1997). ${ }^{11}$

We have described how Blacks are disconnected from jobs and experience bad labour market outcomes. The SMH stipulates a causal link which is supported by a series of econometric studies. ${ }^{12}$ Such recent studies include Raphael (1998) who focuses on how differences in accessibility to areas of high employment growth can account for differences in the employment rates of White and Black youth, showing that nearly 20 per cent of the employment differential can be attributed to systematic accessibility differences. Similarly, Parks (2004) finds that a better spatial accessibility to jobs is associated with a lower unemployment rate among Blacks. ${ }^{13}$ Stoll (1998) shows that growth in job decentralisation increases the unemployment incidence and duration for young Blacks. Weinberg (2000) finds that the residential centralisation of Blacks can account for 48 per cent to 62 per cent of the Black-White employment differential among 18-30-yearolds living in the central cities of large MAs. Weinberg (2004) shows that there is a negative effect of job decentralisation on the Black-White employment differential in central cities. Finally, Martin (2004) shows that, between 1980 and 1990, the unemployment rates of Blacks increased in cities where jobs shifted away from Black locations.

While these recent studies confirm the effect of spatial mismatch on the labour market outcomes of inner-city Blacks, none of them tests a specific mechanism accounting for that effect. The next section presents the possible theoretical channels through which spatial mismatch can be harmful for inner-city minorities and discusses their empirical relevance.

\section{The Mechanisms of Spatial Mismatch}

The general tests of spatial mismatch quoted in the previous section show that the $\mathrm{SMH}$ is empirically grounded. However, they do not shed light on the specific underlying mechanisms. This section presents the mechanisms put forward by the theoretical models and reports the related empirical tests in the literature. We can think of (at least) seven different underlying mechanisms that explain how distance to job opportunities could be harmful. ${ }^{14}$ Explanations (1)-(4) adopt the point of view of minority workers (labour supply), whereas explanations (5)-(7) adopt the perspective of firms (labour demand)

(1) Workers may refuse a job that involves commutes that are too long because commuting to that job would be too costly in view of the proposed wage.

(2) Workers' job search efficiency may decrease with distance to jobs. In other words, for a given search effort, workers who live far away from jobs have fewer chances to find a job because, for instance, they get less information on distant job opportunities.

(3) Workers residing far away from jobs may not search intensively. For instance, when house prices decrease with distance to jobs, distant workers may feel less pressured to search for a job in order to pay their rent.

(4) Workers may incur high search costs that cause them to restrict their spatial search horizon at the vicinity of their neighbourhood.

(5) Employers may discriminate against residentially segregated workers because of the stigma or prejudice associated with their residential location (redlining). In particular, suburban employers may consider that, on average, inner-city residents have bad work habits or are more likely to be criminal (statistical discrimination).

(6) Employers may refuse to hire or prefer to pay lower wages to distant workers because commuting long distances makes them less productive (they are more tired or more likely to be absent).

(7) Suburban employers may think that their White local customers are unwilling to have contacts with minority workers. They thus discriminate against minority workers (customer discrimination) and in 
particular against those located in the central city.

It should be noted that these arguments are not directly based on ethnicity, with the exception of (7) and possibly (5). Explanations (5) and (7) operate because of the separation between city centres and suburbs, but do not involve a mechanism which intensity increases with physical distance. To the best of our knowledge, all these points have been formalised in a spatial setting, with the exception of (7). It should be said that a single model sometimes incorporates several of these points (in particular, see Arnott, 1998 and Anas, 2003) and that some mechanisms are embodied in models that do not always adopt a standard spatial mismatch perspective. In some models, the spatial disconnection between residences and jobs results from free location choices and thus departs from the traditional perspective of the $\mathrm{SMH}$ in which housing choices are supposed to be constrained. While assuming free location choice may be a modelling device used by several authors, this may nevertheless have important implications for the relevance of economic policies. In particular, should differences in labour market outcomes be addressed if they result from free location choices? We do not take part in this debate since the focus of our paper is only to show how labour market outcomes may be related to distance and job opportunities, as was first pointed out by the SMH. Also note, that even though we focus on the standard spatial mismatch pattern, the mechanisms are general and may apply to other situations, including contexts in which unemployed workers in the suburbs are disconnected from suburban jobs. This section details the above-mentioned mechanisms by discussing both models and empirical studies, distinguishing the point of view of workers and that of firms.

\subsection{Spatial Mismatch: The Workers' Perspective}

Commuting costs are too high in view of the offered wages (1). The spatial mismatch empirical literature focused for many years on the role of commuting costs as a deterrent for central-city Blacks to accept distant jobs (since the potential wages net of commuting costs would be too low). In US cities, this mechanism could significantly contribute to the unemployment of inner-city minorities.

Coulson et al. (2001) provide a model that shows how the high commuting costs faced by central-city residents can explain their adverse labour market outcomes when firms locate in the suburbs. The authors consider two asymmetrical zones (a central city or CBD and a suburb or SBD), which form two separate local labour markets. Whereas workers are assigned to a place of residence (for some in the central city, for others in the suburbs), firms endogenously decide whether to locate in the central city or in the suburbs, the suburbs being more attractive due to lower entry costs. Workers can hold a job in either of the two zones, but incur higher transport costs if they work out of their zone of residence. In each zone, workers are heterogeneous with respect to their utility or their capacity to commute out of their zone of residence. This assumption can account for the heterogeneity of locations in each zone. In this context, different individuals anticipate different commuting costs and thus different net wages for potential job offers. The firms' differing entry costs, the heterogeneity of workers with respect to transport costs and the frictions in the job-matching process combine to generate a spatial mismatch situation. The authors show that there exists an equilibrium in which the SBD residents work in their zone of residence (which is more attractive for firms) whereas some residents of the CBD commute daily to the SBD (reverse commuting). In this equilibrium, the number of job vacancies in the CBD is lower than in the SBD, in particular because the entry-cost differential favours job creation in the SBD. Moreover, in the $\mathrm{SBD}$, the unemployment rate is lower and the gross wage is higher than in the CBD. Whereas the CBD residents who bear low commuting costs find SBD jobs attractive, 
those with high commuting costs prefer to search in the CBD even if the unemployment rate is higher there. The model simultaneously accounts for both the low income and the high unemployment rate of city-centre residents.

Following the standard version of the SMH, Brueckner and Martin (1997) and Brueckner and Zenou (2003) propose models which investigate the effect of housing market discrimination on the labour market outcomes of Blacks. The first attempt to model spatial mismatch in a standard urban economics framework was the work of Brueckner and Martin (1997; see also Martin, 1997) which showed how job decentralisation and housing market discrimination combined to depress the wages of minorities. Considering a local labour market at each end of a linear city (a central-city employment centre and a suburban employment centre), the authors presented a comparison 'before' and 'after' the introduction of spatial mismatch in the model-that is, 'with' and 'without' housing market discrimination assigning Blacks to central-city locations. However, this formalisation did not model the effects of spatial mismatch on unemployment rates.

Brueckner and Zenou (2003) propose an extension that bridges this gap. As in Brueckner and Martin (1997), the authors consider a closed linear city with absentee landlords with an employment centre at each end of the segment: the central business district (CBD) and the suburban business district (SBD). They assume that these centres form two separate local labour markets. Labour demand is exogenous and the same in each centre so that it limits the number of available local jobs. There are two continua of individuals, Blacks and Whites, who are distributed in the city and go to work in one centre or the other. Each individual chooses where to search for a job by comparing the expected wages offered in each centre net of commuting costs. The authors assume housing market discrimination so that Blacks are not authorised to live in the suburbs (close to the SBD). In this context, Black workers are skewed towards the CBD and Blacks' residences are thus remote from the
SBD. For a Black worker, working in the SBD involves high commuting costs, which deters many of them from accepting SBD jobs even though some of them accept working in the SBD. As a result, the Black CBD labour pool is large relative to the Black SBD pool. In a simple version of this model, the wages of both Whites and Blacks are set at an exogenous level. Black workers are paid at the minimum wage and Whites are better paid (which could be justified if they are more skilled). In equilibrium, the combination of fixed wages and fixed local labour demand generates unemployment so as to clear the labour market. As the Black labour supply is skewed towards the CBD under housing market discrimination, the unemployment rate of Blacks is higher in the CBD than in the SBD (in conformity with the descriptive statistics presented in section 2.3). Without housing market discrimination (implying that the labour supply of Blacks would be equally shared between the two centres), the unemployment rate of all Blacks would lie between the CBD and SBD unemployment rates that prevail in the restricted equilibrium.

A limit of the fixed-wage setting, however, is that it does not yield any prediction of the effect of spatial mismatch on wages. This limit is addressed in an extension of the model in which the wages of Blacks are endogenously determined to deter shirking. In this efficiency-wage setting, unemployment acts as a worker discipline device which enables employers to pay lower wages when unemployment is higher (see Shapiro and Stiglitz, 1984). In this context, the authors obtain exactly the same result as in the fixedwage setting concerning the unemployment rates. In addition, they also show that Black CBD workers have lower wages than Black SBD workers in the spatial mismatch equilibrium (replicating the stylised facts presented in section 2.3). The wage of all Blacks in the unrestricted equilibrium lies between the CBD and SBD wages of Blacks in the restricted equilibrium.

Concerning empirical work, some authors have tried to test the effect of commuting 
costs in the acceptance or refusal of jobs. ${ }^{15}$ Zax and Kain (1996) analyse the impact of a firm's relocation from Detroit's central city to a White suburb on workers' mobility and employment. They show that, as White employees are confronted with longer commutes, they move to get closer to the firm's new location. However, few Black employees change their place of residence (maybe because they are discriminated against in the housing market in the White suburbs). Moreover, the increase in the commuting distances of Black workers induces many of them to quit their jobs. Fernandez (1994) obtains similar results studying the relocation of a food-processing firm from the centre of Milwaukee to one of its suburbs. The issue of job accessibility is thus crucial and the spatial mismatch mechanism can be amplified when distant workers do not have access to a fast and efficient transport mode. In particular, as cars may be too expensive for some workers, they may have to rely on public transit which may not reach all job locations and may be very time-consuming. In this respect, Kawabata (2003) finds that a better job-access by public transit increases the likelihood of working and the number of hours worked for individuals who do not have a car. The effect is bigger in cities such as San Francisco and Los Angeles because of the city structure than in Boston which is more compact. Ihlanfeldt and Young (1996) show that, in Atlanta, one-third of the differences in Black employment share between centralcity and suburban fast-food restaurants is attributable to the fact that suburban firms are less frequently served by public transit. Holzer et al. (2003) find that the expansion of the railway system in San Francisco to a predominantly White, high-growth and lowunemployment suburb increases the relative employment of minority workers near the station. Raphael and Rice (2002) show that car ownership increases the employment rate and the number of hours worked but, surprisingly, decreases hourly earnings. Ong and Miller (2005) show that the 'transportation mismatch' (the lack of access to a private automobile) is the most important factor in generating poor labour market outcomes, particularly for disadvantaged neighbourhoods in the Los Angeles metropolitan area. Raphael and Stoll (2001) find that raising minority car-ownership rates to the White carownership rate would considerably narrow interracial employment rate differentials.

Job search is inefficient far away from jobs (2). The second mechanism revolves around the decrease with distance in the available information on job opportunities. It suggests that a worker who resides far away from job opportunities has less information about jobs than an individual who resides closer to job opportunities. Indeed, several empirical studies support the idea that physical distance to jobs reduces the available information on the existence and characteristics of job vacancies (see Ihlanfeldt and Sjoquist, 1990; Ihlanfeldt, 1997). One possible reason is that job seekers do not know exactly where to search in distant places they are not accustomed to. They may be less efficient because they search in the wrong locations. Another reason could be that many firms resort to local recruiting methods (such as having advertisements published in local newspapers or by posting 'wanted' signs) which disadvantage distant workers (see Turner, 1997). In this context, Davies and Huff (1972) find that individuals looking for a job can only search efficiently in a restricted perimeter centred around their residence, which could turn out to be inefficient. Stoll (2005) finds that, among the less-educated population of Atlanta and Los Angeles, Blacks and Latinos search for a job in areas with a higher level of job skill requirements than do Whites. Finally, Holzer and Reaser (2000) show that in Atlanta, Boston, Detroit and Los Angeles, unskilled Black workers apply less to suburban jobs than to central-city jobs.

The role of spatial frictions in job search efficiency was first modelled by Wasmer and Zenou (2002) who formalise the link between distance to jobs and unemployment in a searchmatching model (Mortensen and Pissarides, 1999; Pissarides, 2000). In their paper, the authors consider a linear city in which 
individuals endogenously sort themselves at a greater or shorter distance from a unique employment centre, which should be considered as a suburban employment centre if one has in mind the configuration of a US city (see the descriptive statistics on job suburbanisation in section 2.1). The main idea is that search efficiency is reduced with the distance between a searcher's residence and the prospective centre of employment. At the aggregate level, the number of matches between the two sides of the market (workers and firms) depends on the average search efficiency of unemployed workers (given their locations) and on labour market tightness (the number of vacant jobs per unemployed worker) as in traditional job search models. In this model, individuals change their residential location at no cost whenever they experience a change in their employment status, so that occupied and unemployed workers reside in distinct portions of the city. ${ }^{16}$ The model's contribution lies in the existence of several forces that attract unemployed and occupied workers with different intensities. The first one is the fact that the employed workers travel to the job centre more frequently than the unemployed workers so that residing closer to the job centre becomes relatively more attractive for employed workers than for unemployed workers. Conversely, there exists an attraction force towards the job centre that only concerns unemployed workers: the increase in their job search efficiency associated with proximity to jobs. The confrontation of these two opposite forces leads to two possible urban configurations in equilibrium. A first equilibrium, the 'integrated-city equilibrium', has unemployed workers residing close to the employment centre whereas employed workers reside further away. In a second equilibrium, the 'spatial mismatch equilibrium', the opposite is true: employed workers reside close to the employment centre whereas unemployed workers reside at a distance from job opportunities. Which equilibrium prevails depends on a trade-off between the difference in commuting costs per unit of distance for employed and unemployed workers and the expected return of being more efficient in search when unemployed workers reside marginally closer to the employment centre. The spatial mismatch equilibrium prevails when the expected return associated with search efficiency is lower than the difference in commuting costs between employed and unemployed workers. In this case, employed workers are willing to pay higher land rents than unemployed workers to live closer to the suburban employment centre and bid away unemployed workers at a distance from jobs (i.e. close to the historical centre). In this spatial mismatch configuration, unemployed workers who are far away from jobs have little chance of finding a job. The overall unemployment rate is higher and the search efficiency is lower when unemployed workers reside at a distance from jobs than in the other equilibrium in which they reside close to jobs.

Observe that the lack of information generated by distance to jobs can also involve local social interactions. The key intuition is that, in a neighbourhood far from jobs, all workers are affected by distance so that the unemployment rate in the neighbourhood is high. It is thus all the more difficult for each individual to rely on personal connections to refer them to jobs as many neighbours are themselves unemployed, so that unemployment is further exacerbated (Mortensen and Vishwanath, 1994; Calvo-Armengol, 2004; Selod and Zenou, 2006).

The empirical evidence is consistent with the model's findings. Rogers (1997) and Immergluk (1998) argue that, for informational reasons, the workers who reside close to jobs remain unemployed for a shorter period of time. In US cities, Blacks are far away from job opportunities (see section 2.2) and the mechanism should thus apply to them. Stoll and Raphael (2000) show that Whites have a better job search quality than Blacks because they search in areas where employment growth is higher and that the difference in spatial job search quality between Whites and Blacks explains nearly 40 per cent of the difference in their employment rates. Holzer and Reaser (2000) show 
that less-educated Black males (who search less in the suburbs) are less likely to be hired in the suburbs. They attribute this result to low information flows (but also to higher costs of applying). More accurate studies would certainly be needed to determine explicitly how distance affects unemployment through its negative effect on job search efficiency. For instance, one could think of a two-equation model. In a first equation, the number of obtained job offers would be explained by distance to job opportunities. In a second equation, the individual probability of unemployment would be explained by the number of job offers reaching the individual and by an index of distance to job opportunities. The reason for introducing the latter index is to control for all other mechanisms affecting unemployment and involving distance. It is then possible to rewrite the second equation in reduced form using the first equation. Estimating both the reduced form and the first equation would make it possible to evaluate the effect of distance on unemployment through job search. ${ }^{17}$ Of course, this would require very specific individual and spatial data.

Distant workers do not search intensively for a job (3). Another mechanism which can explain unemployment patterns in US cities relies on the incentives to search for a job. Smith and Zenou (2003) propose a model that focuses on the job search intensity of workers. The authors consider a searchmatching framework with housing in an urban context similar to that of Wasmer and Zenou (2002, 2006) except that land consumption is now endogenous. In their model, when an unemployed worker increases his search intensity, he incurs a loss in utility in the short run because of higher transport costs (more frequent search trips) and a lower housing consumption (because of a lower net disposable income, housing being a normal good). However, he gains in the long run because searching more intensively increases his chances of obtaining a job and thus his lifetime surplus (because he can expect a higher expected income). In this context, each unemployed worker determines his optimal search intensity by equating the short-run losses with the long-run gains. When it comes to choosing their residential location, unemployed workers face the following trade-off: because of high rents, locations near the employment centre are costly in the short run but allow higher search intensities, which in turn increase the long-run prospects of re-employment. Conversely, locations far away from the employment centre are more desirable in the short run (because of low rents) but allow only infrequent trips to the employment centre and hence reduce the long-run prospects of re-employment. Under some assumptions, the authors show that three different equilibria can prevail. The 'integrated-city equilibrium' and the 'spatial mismatch equilibrium' (as in Wasmer and Zenou, 2002) and a 'coreperiphery equilibrium', where short-run unemployed workers reside close to jobs while those who are long-run unemployed live far away from jobs, the employed living in between them. In the last two equilibria, there is a group of unemployed workers who reside far away from jobs, live in cheap dwellings and are thus not induced to search very hard for jobs. They will remain unemployed for a long time. This model formalises a mechanism supporting the spatial mismatch hypothesis: if Black workers live far away from jobs where housing is cheap, then they will be induced to search less intensively than if they lived closer to jobs in more expensive dwellings.

Using English sub-regional data, Patacchini and Zenou (2006) empirically confirm that living in areas where rents are higher induces workers to search more for a job: a one-standard deviation increase in housing prices raises search intensity by about onethird of a standard deviation. However, a complete test of the model should relate distance to jobs to land rents, search intensities and employment outcomes.

Search costs deter workers from searching far away (4). When search costs are high, workers may be deterred from searching far 
away from their residential location and may restrict their search horizon to their neighbourhood or its close vicinity, even if the neighbourhood only offers a few low-quality jobs. Some empirical evidence already mentioned in (2) is also consistent with the assumptions in (4) (Stoll, 2005; Holzer and Reaser, 2000). ${ }^{18}$ Other studies, however, are more specific to (4). For instance, Stoll (1999) shows that increasing Blacks' access to cars or decreasing their average distance to search areas (thus decreasing their search costs) should lead to a more extensive geographical job search. Holzer et al. (1998) find that Blacks cover less distance than Whites while searching.

High search costs may deter inner-city minorities from searching in the suburbs where jobs are located, explaining their bad labour market outcomes. The mechanism was first modelled by Ortega (2000) in a two-area search-matching framework. Contrary to Wasmer and Zenou (2002), the author assumes that jobs are located in two different areas (that we will interpret as a city centre and its suburbs). Workers choose in which area to search. At each point in time, some jobs are destroyed, but the destruction rate is exogenous and higher in the central city than in the suburbs. The main assumption in this model is that the search costs differ depending on whether workers search in their area of residence or in the other area. ${ }^{19}$ Indeed, searching in the other area involves additional travel: search costs are assumed to be zero in the home area and strictly positive in the host area. Under this assumption, central-city residents (respectively suburban residents) have higher costs to search in the suburbs (respectively in the city centre) than to search in the city centre (respectively in the suburbs). The efficiency of job search is endogenously determined in each area and depends on the local labour market tightness. Individuals choose where to search for a job by trading off the efficiency and the cost of job search. When the probability of finding a job is higher in the suburbs than in the central city, centralcity residents face a trade-off between the benefit of a more efficient job search in the suburbs and its higher cost. The main result of the model is that, when the search cost is too high, central-city residents have no incentive to search for a job in the suburbs and the unemployment rate in the city centre is higher than in the suburbs. Suburban wages bargained by central-city residents are lower than those bargained by suburban residents for suburban jobs. This asymmetry results from the high search cost that lowers the bargaining power of individuals at a distance from their place of residence.

We do not know of any paper providing a relevant empirical test of how distance to job opportunities can explain labour market outcomes through search costs. As in (2), one may want to rely on a two-equation specification. In a first equation, search costs would be explained by distance to job opportunities. In a second equation, the individual probability of unemployment would be explained by the search cost variable and an index of distance to job opportunities. This strategy would make it possible to isolate what part of the effect of distance on unemployment can be attributed to search costs. However, it is hard to come up with a relevant variable to measure search costs as one would like the proxy to be unrelated to commuting costs. In particular, a car-ownership dummy cannot be used to proxy for search costs as the transport mode is also related to commuting costs.

\subsection{Spatial Mismatch: The Firms' Perspective}

Distance may yield bad labour market outcomes because employers are reluctant to hire workers who live far away from their workplace or in other neighbourhoods. The next three mechanisms provide justifications for this behaviour.

Territorial discrimination (5). A segregated spatial structure in which ethnic minorities are spatially disconnected from jobs can give rise to employer discrimination on the basis of the applicant's residential location (redlining). As far as the labour market in US cities is concerned, suburban employers may 
discriminate against inner-city residents-for instance, because they view them as more likely to be criminal, dishonest or having bad work habits.

Zenou and Boccard (2000) provide a model in which redlining can amplify unemployment problems. The authors consider a linear city in which all jobs are grouped in a single employment centre. There are two continua of Black and White workers that can be employed or unemployed. Both groups commute to the employment centre, endogenously decide where to locate in the city and the quantity of land they want to consume, land being a normal good. The two groups differ since Blacks bear a higher commuting cost per unit of distance than Whites and since they are discriminated against by employers (so that it is more difficult for them to get a job). Irrespective of their residential location, Blacks are thus more unemployed than Whites. Two different urban equilibria can occur depending on a trade-off between transport costs and land consumption: when the transport cost of Blacks is high enough, they bid away all Whites from the vicinity of the employment centre which thus gathers all unemployed and employed Blacks (equilibrium 1). When the transport cost of Blacks is sufficiently low, then Black and White unemployed workers alike locate close to the employment centre whereas Black and White employed workers locate at the other end of the city where they can consume more land since they are richer (equilibrium 2 ). In other words, when the transport cost of Black workers is sufficiently large, a city is segregated by race. When the transport cost of Black workers is sufficiently small, a city is segregated by employment status. In this framework, the authors introduce redlining which they model as an additional labour market discrimination on all the workers residing close to the employment centre. In the first equilibrium, Blacks are discriminated against both racially and spatially (because of redlining) and thus their unemployment rate is very high. In the second equilibrium, redlining increases the unemployment rate of both Blacks and Whites since all unemployed workers gather around the employment centre. An interesting feature of that model is that it shows how redlining can differently affect minorities depending on the city structure and on who resides beyond the 'red line'. A truly SMH perspective, however, would require changing the model's assumptions. Indeed, it would have been more relevant to have Blacks located far away from jobs and employers redline this zone instead of the employment centre. ${ }^{20}$

To our knowledge, the effect of redlining on the labour market outcomes of Black workers has not been investigated empirically. It would be interesting to test whether redlining matters, as the popular press often relates stories about firms that do not want to hire workers living in 'bad' neighbourhoods (see Wilson, 1996) and which are in general not well-connected to jobs. An empirical test of the mechanism could rely on the standard methodology used to investigate the existence of redlining on the housing market (see section 2.2 for references).

The productivity of distant workers is too low (6). Employers may consider that distance to jobs deteriorates productivity because of long commuting trips. This can be the case if distant workers are more likely to be late or tired or reluctant to provide high levels of effort than those who reside closer to jobs. This is particularly true for some jobs (such as working in a restaurant) which involve long breaks during the day (typically between 2 p.m. and 6 p.m.). The workers who live nearby can go back home and relax whereas the workers that live further away cannot rest at home, which certainly affects their productivity. Also, because of the lack of good public transport in US metropolitan areas, downtown workers living far away from jobs may have relatively low productivity at suburban jobs because they arrive late to work due to the unreliability of the mass transit system that causes them frequently to miss transfers. As a consequence, firms may determine a geographical boundary beyond which they will not recruit workers. 
This idea has been modelled by Zenou (2002) in the context of a monocentric city where all firms are located in the city centre. Each worker chooses whether to shirk or not. When shirking, the worker provides no effort. When not shirking, he provides an effort that contributes to production but decreases his utility. In accordance with the above remarks, the author assumes that the provided effort decreases with distance to the workplace. The worker's contribution to production depends on its effort (and thus on its proximity to the firm). Unemployed workers commute to the employment centre to search for a job, but at a less frequent pace than employed workers. This means that employed workers would lose more in terms of utility than unemployed workers from residing marginally further away from the employment centre. Consequently, employed workers always bid away unemployed workers to reside closer to the employment centre. As in Brueckner and Zenou (2003), the wage is determined in an efficiency-wage setting to deter workers from shirking. If a worker is caught shirking, he is automatically fired. As employed workers differ in their locations and thus in their productivities, the perworker profit decreases with distance to jobs. Firms anticipate that remote workers will provide lower effort levels and do not recruit workers beyond a certain distance where the per-worker profit is zero. This model yields a realistic city structure (unemployed workers residing far away from jobs) as in spatial mismatch models that adopt the workers' perspectives. It also explains why some areas that are stigmatised are also far away from jobs.

To our knowledge, no empirical test of the mechanism has been carried out yet. Estimating this mechanism would require to have a dataset with information on firms' evaluation of candidates for given vacancies. The different categories should include a statement about the candidate's productivity with respect to his distance from the job location considered. A two-equation specification could be used. First, the productivity statement would be explained by distance. Secondly, the probability of rejection would be explained by the different evaluation categories and by the distance between the vacancy and the worker's residence. This would separate the productivity effects from other effects involving distance.

Customer discrimination (7). Finally, another type of spatial discrimination consistent with spatial mismatch involves the preferences of customers. Customer discrimination corresponds to a situation in which an employer discriminates against ethnic minorities to please local customers who do not wish to be in contact with other racial groups. In the context of US cities where segregation and prejudice are high, this means that services firms located in White suburbs are likely to discriminate against Black workers, most of them residing in inner cities. Borjas and Bronars (1989) propose a theoretical model of customer discrimination in which White customers are reluctant to pay for a good when it is sold by a self-employed Black. However, we do not know of a spatial model which would relate customer discrimination in the suburbs to the centralisation of Blacks in the city.

A series of empirical studies have shown that customer discrimination could contribute to the poor labour market outcome of minority workers. In their study of the wage gradient of fast-food restaurants within Atlanta, Ihlanfeldt and Young (1994) find evidence that consumer prejudice affects the wages paid to Black workers. More precisely, they find that, as distance from the CBD increases, there exists a negative effect on wages from greater customer discrimination (even though this negative effect is strongly dominated by a positive wage gradient effect). Other studies focus on how customer discrimination might affect the hiring of minority workers. For instance, Ihlanfeldt and Young (1996) find that the share of fast-food restaurant jobs held by Blacks is smaller in the suburbs of Atlanta than in the central-city and that 29 per cent of the difference in Black employment share between central-city and suburban firms is attributable to the city-suburban differences in the race of managers and customers. In a 
similar perspective, Holzer and Ihlanfeldt (1998) estimate that the racial composition of an establishment's customers has sizeable effects on the race of who gets hired, particularly in jobs that involve direct contact with customers. More recently, Raphael et al. (2000) show that both suburban Black and White employers hire fewer Blacks than their central-city counterparts, but are not able to assess whether this is due to spatial frictions or to the discriminatory preferences of suburban employers relative to their central-city counterparts.

\section{Policy Implications}

What are the lessons for policy design that can be derived from the current empirical and theoretical state of the knowledge concerning spatial mismatch? In this section, we argue that the relevance and efficiency of the different policies can depend on the mechanism at work.

Spatial mismatch has inspired policies around three main strategies: helping Blacks to move to suburban locations; attracting adequate jobs to the city centre; and improving informational or physical connections between inner-city Black workers and suburban jobs (see Hugues, 1995; Ihlanfeldt and Sjoquist, 1998). The first two strategies would directly suppress the causes of spatial mismatch whatever the mechanism at work. The general tests of the SMH which have recently been conducted are supportive enough to justify these types of policy. By contrast, the third approach does not focus on bringing people and jobs to the same locations but, rather, on alleviating the adverse consequences of spatial mismatch: the choice of policies of this type should depend on the mechanisms that empirically prevail.

Concerning the first strategy-helping Blacks move to suburban locations-a straightforward policy that comes to mind is to address housing market discrimination by enforcing the law. However, this may be insufficient to improve the access of poor minorities to suburban jobs if they do not have a sufficient income to pay for a suburban rent, which justifies social-mixing policies providing financial support. In this context, the two major experiences implemented in US cities are the Gautreaux programme (implemented in Chicago between 1976 and 1990) and the Moving to Opportunity programme or MTO (implemented in five major citiesBaltimore, Boston, Chicago, Los Angeles and New York-between 1994 and 1999). The Gautreaux programme targeted Black families residing in poor neighbourhoods and handed them rental vouchers to move to predominantly White or racially mixed areas. The MTO programme was inspired by the Gautreaux programme but the target was inner-city lowincome families with children living in public housing. These two programmes were not explicitly designed to address spatial mismatch issues but rather to address residential segregation, with the hope that residential mobility would have a positive effect on employment and wages. The hope was motivated given the better outcomes of racially mixed areas. Assessing the employment effects of the Gautreaux programme, Rosenbaum (1991, 1995) finds higher employment but no difference in wages or hours worked for those who moved to the suburbs compared with those who moved to the central city. Mendenhall et al. (2006) study the effect of the programme on lowincome Black females and find no difference between movers to suburbs and movers to the central city. However, these results are difficult to interpret since it would be more relevant to compare movers and stayers (and even more relevant to compute a counterfactual for movers had they remained in their central-city neighbourhood). Unfortunately, it is not possible to do such a comparison with the data from the Gautreaux programme as there is no control group. This can be done assessing the effects of MTO. However, Katz et al. (2001) find no effect of MTO on either employment or earnings. In any case, there is still an issue if one wants to use the data from the MTO programme to study the effect of reducing the disconnection between people and jobs: the issue is that one can choose where to relocate (under the constraint that the neighbourhood of destination is less segregated than the neighbourhood of origin). This does not necessarily 
mean that they are going to get closer to job opportunities. To study this issue, an adapted controlled experiment could replicate the MTO methodology but would constrain people to relocate only in neighbourhoods with a better job accessibility.

Concerning the second option-attracting adequate jobs to the city centre-several policies may be justified. Some policies may offer subsidies to firms if they locate in specific enterprise zones. Others may develop infrastructure (services, transport, etc.) that will increase the attractiveness of some locations. To our knowledge, studies on these topics are scarce. One exception is Bollinger and Ihlanfeldt (2003) who study a neighbourhood-based tax incentive within Atlanta and show that it has a positive effect on the neighbourhood's share of regional employment. They also show that highway improvements increase a neighbourhood's employment share. However, what remains to be shown is whether the effect on local hiring is significant. Indeed, firms might relocate in neighbourhoods keeping their employees but not hiring local ones. Observe that policies that only aim to improve infrastructure can hardly influence the type of jobs that they might attract and, in any case, cannot force firms to hire local workers. Conversely, tax-incentive policies can target the type of eligible jobs and have the option to impose the condition that a proportion of local workers should be hired.

Turning to the third option-improving connections-several transport policies have been implemented in the US ranging from investments in public transport to vouchers to buy cars (see Pugh, 1998, for an enumeration). In general, the aim of spatial mismatch motivated public transport policies has been to decrease commuting costs in terms of distance, time and money (through subsidies) between inner cities and suburbs. To our knowledge, the effects of transport policies on employment have not been fully evaluated. Although such policies are likely to have an effect, one should be aware of two major limits. First, connecting inner cities to suburbs (i.e. facilitating reverse commuting along the traditional view of the spatial mismatch hypothesis) may not be adequate for individuals with specific transport schemes: some poor people may need to commute within suburbs or within the central city (Blumenberg and Waller, 2003). In addition, some people may have to travel in different directions and to stop at many places (for example, single mothers who have to shop, bring their child to school and go to work; Blumenberg, 2004). Due to waits at connecting-points, this can be costly and time consuming even if the transport network seems affordable and quite efficient. In this context, the ownership of a car is crucial. Policies to promote car ownership among low-income households have already been implemented and it might be fruitful to extend their scope (Blumenberg and Waller, 2003; Blumenberg and Manville, 2004) especially since car ownership has a positive effect on the employment of minorities (Raphael and Stoll, 2001).

The second limit of transport policies is that lowering commuting costs may not always be the adequate way of connecting people and jobs. Indeed, other mechanisms may account for the harmful effect of distance. When the problem is one of high search costs and lack of information, transport policies are still adapted but can be complemented with other policies aiming directly to improve the knowledge that job seekers get on vacancies from their neighbourhood (i.e. a local agency gathering information on all vacancies in the metropolitan area). When the prevalent mechanism hinges upon the reluctance of employers to hire workers whose punctuality may depend on an inefficient transport system, then transport policies may have an effect. When the motivation is not linked to transport (as with redlining or with customer discrimination), anti-discrimination policies are needed. It is thus important to determine empirically which mechanisms operate in order to adopt relevant policies.

\section{Conclusion}

The spatial mismatch hypothesis originally formulated by Kain (1968) supports the view 
that because Black workers reside in segregated zones that are distant and poorly connected to major centres of growth, they are confronted with barriers to finding and keeping well-paid jobs. The objective of our work has been to present the most recent theoretical contributions to the spatial mismatch literature and to confront them with the existing empirical evidence, as it has not been done before.

We have presented the structure of American cities (in which unemployed or poorly paid central-city Black workers are often disconnected from suburban job opportunities) and explained how this structure can emerge using urban economic theory. We have reviewed recent theoretical models related to the spatial mismatch literature to shed light on why residing at a distance from jobs can be harmful for ethnic minorities and have discussed how these models and their findings fit in the spatial mismatch debate. We have identified seven different mechanisms that can lead to adverse labour market outcomes in a spatial mismatch context. Each mechanism takes the perspective of either workers or firms. Workers who reside far away from job opportunities may be confronted with high commuting costs that may deter them from accepting distant job offers. They may experience poor efficiency and high costs in the job search process. They may also have few incentives to search for a job if, for instance, they do not have to pay high rents. Concerning suburban firms, employers may discriminate against Black inner-city residents for redlining motives, or against Blacks to satisfy the prejudice of their local customers. They may also be reluctant to hire long-distance commuters because of the negative effect of commuting on productivity. To our knowledge, all these mechanisms have been modelled in a spatial perspective, with the exception of customer discrimination.

On the empirical side, there is some clear evidence supporting the effect of commuting costs and customer discrimination on unemployment. There is also suggestive evidence that the increase in search costs and the decrease in search efficiency with distance can cause unemployment. However, it appears that the search incentive, productivity and redlining assumptions have not been empirically investigated. Further empirical studies are required to test these mechanisms and to assess their relative intensities.

The focus of this abundant literature has mainly been on Blacks following the initial formulation of the SMH. However, several studies have shown that spatial mismatch is also an issue for other ethnic groups (Hispanics, Asians) but only to a lesser extent (Ihlanfeldt, 1993; Raphael and Stoll, 2002). One may wonder what makes the cases of those other ethnic groups different from that of Blacks. Is it due to differences in housing discrimination or residential location choices? In access to transport? In skills and the jobs they may occupy? Further studies are probably needed in a comparative perspective across minority groups.

It is acknowledged that there are three ways to address spatial mismatch: bringing jobs to people, bringing people to jobs, connecting people and jobs (Ihlanfeldt and Sjoquist, 1998). The first two policy types are meant to suppress spatial mismatch directly, whereas the third policy aims to reduce the disadvantages associated with physical disconnection from jobs. Surveying the theoretical mechanisms underlying spatial mismatch provides some additional insights for policy design of the third type. Policies to improve connecting people and jobs should target the specific mechanism at work. Transport policies are adapted when the problem is high search and commuting costs. Information policies (such as central-city employment agencies gathering information on suburban jobs) should complement transport policies when search efficiency is reduced due to the small amount of information that central-city residents have on distant job opportunities. Anti-discriminatory policies are recommended in a spatial mismatch perspective when employers adopt discriminating behaviours that hinge upon the city structure (redlining, customer discrimination). It is thus necessary to identify empirically which specific mechanisms prevail. 
It is important to mention that the spatial disconnection between central-city workers and suburban jobs is not the only spatial barrier to employment. There are also centralcity workers disconnected from some corresponding central-city jobs, as well as suburban workers disconnected from job opportunities in the suburbs. Job connection policies should probably take into account the variety of spatial patterns that may act as barriers to employment in US cities (Blumenberg and Waller, 2003). This calls for further empirical studies assessing the relative importance of those different spatial patterns and their effect on labour market outcomes.

\section{Notes}

1. The SMH should not be considered the unique cause of the difficulties faced by inner-city minorities. In no way does the SMH rule out the possibility of alternative explanations such as sheer labour market discrimination (Becker, 1971; Bertrand and Mullainathan, 2004), the harmful effect of residential segregation through adverse social interactions (Crane, 1991; Cutler and Glaeser, 1997) and exclusion from union membership (either because there is no union at the places where minorities work or because of racial discrimination on the part of unions).

2. In line with the bulk of the spatial mismatch literature, our survey essentially focuses on Blacks.

3. An empirical controversy was initiated by Ellwood (1986) for whom race is a much more important factor than job accessibility in explaining the adverse labour market outcomes of minorities. A discussion of this empirical controversy in the 1980s and 1990s is provided by Kain (1992) and Ihlanfeldt and Sjoquist (1998). In general, recent studies tend to be more supportive of the SMH.

4. We provide figures for large cities given that spatial mismatch is known to be a big city issue (see Ihlanfeledt and Sjoquist, 1998; for a comparison of the degree of spatial mismatch in large and small MSAs, see Table 1 in Selod and Zenou, 2006, and our comments in section 2.2 of the present paper). The 10 largest MSAs are, in decreasing order: (1) Los Angeles-Long Beach, (2) New York, (3) Chicago, (4) Boston, (5) Philadelphia, (6) Washington, (7) Detroit, (8) Houston, (9) Atlanta and (10) Dallas. In 2000, these 10 MSAs contained 85 million inhabitants, representing 27 per cent of the total US population living in MSAs. All our figures are calculated from the State of the Cities Data System (http://socds.huduser.org) in which the breakdown between city centres and suburbs corresponds to the Census Bureau's definition. We acknowledge that the definition of a city centre could be problematic as it is based to a large degree on political boundaries. It would thus be interesting to recalculate the same figures redefining the boundaries of city centres using a density criterion as proposed by Cervero et al. (2002). We leave this for future research.

5. For a given distribution of population, the suburbanisation of jobs can also be driven by the discriminating behaviour of some firms which flee from minority neighbourhoods located in city centres. For instance, using data from a representative sample of employers in Boston, Atlanta, Los Angeles and Detroit, Iceland and Harris (1998) show that the higher the proportion of Blacks in a neighbourhood, the more likely firms are to express relocation intentions.

6. Manual jobs are those held by machine operators and other labourers. Services jobs are protective, private household and other services. Unfortunately, the SOCDS data do not distinguish between skilled and unskilled services jobs.

7. The concentration of Blacks in US cities dates back to the first half of the 20th century during the Great Migration from the rural South (Collins, 2000), culminating in the 1940s and lasting until the 1960s. The interstate mobility of Blacks was motivated by push factors (crop destructions by the boll weevil in the 1910-20 period and strong racial prejudices in the South) and a pull factor (job creations in the manufacturing sector located in and near cities). Whereas Blacks were interregionally very mobile, their within-city mobility remained rather low while cities expanded. The present paper focuses on the consequences of the low intracity residential mobility of Blacks on their labour market outcomes from a spatial mismatch perspective.

8. Residential segregation is measured by the dissimilarity index, also known as the Duncan and Duncan index (1955). By definition, the dissimilarity index is equal to

$$
\frac{1}{2} \sum_{i}\left|\frac{\text { Blacks }_{i}}{\text { Blacks }}-\frac{\text { Non }- \text { Blacks }_{i}}{\text { Non }- \text { Blacks }}\right|
$$

where, $i$ is a district (typically a census tract). 
It measures the percentage of Blacks (or similarly of non-Blacks) that should be relocated in order to obtain a homogeneous distribution of population in the city. A dissimilarity index of less than 30 per cent is considered to be low. Between 30 per cent and 60 per cent, it is medium. Over 60 per cent, it is considered to be high (Cutler et al., 1999). The dissimilarity index is sensitive to the size and shape of districts.

9. Observe that the degree of spatial mismatch varies across minorities. In particular, the 2000 dissimilarity index between the residences of Hispanics and jobs was 44 per cent, whereas the dissimilarity index between the residences of Hispanics and retail jobs was 43 per cent. The disconnection between Hispanics and jobs is usually lower than that of Blacks but above that of Whites (Raphael and Stoll, 2002).

10. A positive wage gradient is not observed for all jobs. As a matter of fact, the wage gradients of high- and low-skilled jobs are thought to be of opposite signs. The highskilled jobs that pay the most are located within the CBD, whereas the low-skilled jobs that pay the most are located in the suburbs. In theory, the positive wage gradient of low-skilled jobs in US cities could be explained by the decentralisation of these jobs combined with the suburban residential exclusion of low-skilled workers. The negative gradient of high-skilled jobs could be explained by the specialisation of CBDs. When one considers all jobs taken together, wages are 10 per cent to 35 per cent higher in city centres than in the suburbs (Stanback, 1991).

11. In the suburbs, poverty rates are lower for both Whites and Blacks, but, just as in central cities, Blacks are more affected by poverty than Whites: in 1990 , only 6.6 per cent of suburban Whites but 19.5 per cent of suburban Blacks were poor (Mills and Lubuele, 1997).

12. Only studies published after 1998 are reviewed in the present paper. For previous references, see the empirical survey by Ihlanfeldt and Sjoquist (1998). The evidence of spatial mismatch in European cities is a very recent literature: see Fieldhouse (1999), Houston (2001, 2005a, 2005b) and Patacchini and Zenou (2005) on Great Britain; see Åslund et al. (2006) on Sweden; see Dujardin and Goffette-Nagot (2005), Gobillon and Selod (2007) and Gobillon, Magnac and Selod (2007) on France; see Dujardin et al. (2008) on Belgium.

13. Measuring 'access to job opportunities' is challenging. Obviously, what matters for a given worker is the number of job vacancies per job seeker within the worker's maximum commuting area, possibly weighted with a distance-decay function (Ihlanfeldt, 2006) or taking into account available transport modes (Shen, 2001; Kawabata, 2003). In this class of indicators, competition for jobs is accounted for by the local pool of job seekers. The main problem is data availability: job vacancies are seldom available at a local level. Local employment levels or local employment growth are thus often used as proxies. The number of job seekers is also often lacking and proxied by the number of unemployed workers or by the total number of workers in the area. Whether these approximations are too crude remains a source of debate. The relevance of these proxies could be tested with a dataset including information on job vacancies and job seekers.

14. We have set aside a potential mechanism involving unions that has not been formalised or empirically investigated in the context of US cities. The intuition is that unions in the suburbs mainly defend the interest of the majority White workers and may thus discriminate against Blacks. In particular, this could explain the difficulty of minority residents from inner cities in obtaining a well-paid entry-level job in the suburbs.

15. It is important to understand that, although it may be tempting to regress labour market outcomes on commuting times or distances, using commuting measures is inappropriate since spatial mismatch is theoretically consistent with both long and short commutes (DeRango, 2001). Indeed, if inner-city Blacks only had the choice between holding a suburban job and being unemployed, one would expect to observe long commuting times and distances. However, disconnection from jobs might induce some workers to accept possibly inadequate jobs close to their residence in the central city, which then mechanically lowers the average commute of inner-city occupied Black workers.

16. This simplifying assumption is not completely realistic. In a recent work, Wasmer and Zenou (2006) have extended this model to the case where workers incur mobility costs when changing residence. Their main conclusion concerning the mechanism of spatial mismatch remains unchanged.

17. Formally, the first equation writes

$$
\text { OFFERS }=a \cdot D I S T+\mathbf{X} \cdot b+\varepsilon
$$


The second equation writes

$$
\begin{aligned}
U N E M P= & c \cdot O F F E R S+d \cdot D I S T+\mathbf{Z} \\
& \cdot e+\eta
\end{aligned}
$$

To address a potential endogeneity problem (OFFERS can be correlated with $\eta$ through $\boldsymbol{\epsilon})$, the second equation should be rewritten in reduced form

$$
\begin{aligned}
U N E M P= & (a \cdot c+d) \cdot D I S T+\mathbf{X} \cdot(c \cdot b) \\
& +\mathbf{Z} \cdot e+\varphi
\end{aligned}
$$

The reduced form and the first equation then make it possible to identify the effect of distance on unemployment through job search $(a \cdot c)$ provided that an exclusion restriction is imposed. Namely, a variable in the vector $\mathbf{X}$ should be excluded from the vector $\mathbf{Z}$.

18. In these two empirical studies, it is not possible to distinguish whether the findings support the assumptions in (2) or (4). The distinction would be possible with more precise data on the job search of workers.

19. In the original model, the areas are two countries and the cost is one of migration.

20. The model would have Blacks locate far away from the employment centre under the assumption that they have a lower commuting cost per unit distance than Whites. In practice, it can be debatable whether Blacks have higher or lower transport costs than Whites. In fact, Blacks resort more to public transport than Whites, which involves a small monetary unit transport cost but a high time cost.

\section{References}

Aigner, D. and CAIN, G. (1977) The statistical theories of discrimination in labor markets, Industrial and Labor Relations Review, 30, pp. 175-187.

AKERlof, G. (1997) Social distance and social decisions, Econometrica, 65, pp. 1005-1027.

Anas, A. (2003) Prejudice, exclusion and compensating transfers: the economics of ethnic segregation, Journal of Urban Economics, 52, pp. 409-432.

Anas, A., Arnott, R. and Small, K. (1998) Urban spatial structure, Journal of Economic Literature, 36, pp. 1426-1464.

ARnOtT, R. J. (1998) Economic theory and the spatial mismatch hypothesis, Urban Studies, 35, pp. $1171-1185$.

Åslund, O., Östh, J. and Zenou, Y. (2006) How crucial is distance to jobs for ethnic minorities?
Old question-improved answer. Discussion Paper No. 5586, Center for Economic and Policy Research, Washington, DC.

Becker, G. (1971) The Economics of Discrimination, 2nd edn. Chicago, IL: University of Chicago Press.

Benabou, R. (1993) Workings of a city: location, education, and production, Quarterly Journal of Economics, 108, pp. 619-652.

Bertrand, M. and Mullainathan, S. (2004) Are Emily and Greg more employable than Lakisha and Jamal? A field experiment on labor market discrimination, American Economic Review, 94, pp. 991-1013.

BlumenberG, E. (2004) En-gendering effective planning: transportation policy and low-income women, Journal of the American Planning Association, 70(3), pp. 269-281.

Blumenberg, E. and Manville, M. (2004) Beyond the spatial mismatch: welfare recipients and transportation policy, Journal of Planning Literature, 19(2), pp. 182-205.

Blumenberg, E. and Waller, M. (2003) The long journey to work: a federal transportation policy for working families. The Brookings Institution Series on Transportation Reform, Center on Urban and Metropolitan Policy, Washington, DC.

BoArnet, M. and Bogart, W. (1996) Enterprise zones and employment: evidence from New Jersey, Journal of Urban Economics, 40, pp. 198-215.

Bogart, W. (1998) The Economics of City and Suburbs. Upper Saddle River, NJ: Prentice-Hall.

Bollinger, C. and Ihlanfeldt, K. (2003) The intra-urban distribution of employment: which government interventions make a difference?, Journal of Urban Economics, 53, pp. 396-412.

Bondonio, D. and EngBerg, J. (2000) Enterprise zones and local employment: evidence from the states' programs, Regional Science and Urban Economics, 30, pp. 517-549.

Borjas, G. and Bronars, S. (1989) Consumer discrimination and self-employment, Journal of Political Economy, 97, pp. 581-605.

Brueckner, J. and MARtin, R. (1997) Spatial mismatch: an equilibrium analysis, Regional Science and Urban Economics, 27, pp. 693714.

Brueckner, J. and Zenou, Y. (2003) Space and unemployment: the labor-market effects of spatial mismatch, Journal of Labor Economics, 21 , pp. 242-266.

Calvo-Armengol, A. (2004) Job contact networks, Journal of Economic Theory, 115, pp. $191-206$.

Cervero, R., Tsai, Y., Dibb, J. et al. (2002) Reverse commuting and job access in California: markets, needs and policy prospects. 
Research Report No. UCB-ITS-RR-2002-7, Institute of Transportation Studies, University of California at Berkeley.

Collins, W. (2000) African-American economic mobility in the 1940s: a portrait from the Palmer survey, Journal of Economic History, 60, pp. 756-781.

Coulson, E., Laing, D. and Wang, P. (2001) Spatial mismatch in search equilibrium, Journal of Labor Economics, 19, pp. 949-972.

Courant, P. and Yinger, J. (1977) On models of racial prejudices and urban residential structure, Journal of Urban Economics, 4, pp. 272-291.

Crane, J. (1991) The epidemic theory of ghettos and neighborhood effects on dropping-out and teenage child-bearing, American Journal of Sociology, 96, pp. 1226-1259.

Cutler, D. and Glaeser, E. (1997) Are ghettos good or bad?, Quarterly Journal of Economics, 112 , pp. 827-872.

Cutler, D., Glaeser, E. and Vigdor, J. (1999) The rise and decline of the American ghetto, Journal of Political Economy, 107, pp. 455506.

DAvies, S. and HufF, D. (1972) Impact of ghettoization on black employment, Economic Geography, 48, pp. 421-427.

DeRANGo, K. (2001) Can commutes be used to test the spatial mismatch hypothesis?, Urban Studies, 38, pp. 1521-1529.

Dujardin, C. and Goffette-Nagot, F. (2005) Neighbourhood effects, public housing and unemployment in a French city. Working Paper No. 2005-05 GATE (Groupe d'Analyse et de Théorie Economique).

Dujardin, C., Selod, H. and Thomas, I. (2008) Residential segregation and unemployment: the case of Brussels, Urban Studies, 45(1) (forthcoming).

Duncan, G. and Zuberi, A. (2006) Mobility lessons from Gautreaux and moving to opportunity, Journal of Law and Social Policy, 1(1), pp. $110-126$.

Duncan, O. and Duncan, B. (1955) A methodological analysis of segregation indices, American Sociological Review, 20, pp. 210217.

Ellwood, D. (1986) The spatial mismatch hypothesis: are there teenage jobs missing in the ghetto?, in: R. FreEMAN and H. Holzer (Eds) The Black Youth Unemployment Crisis, pp. 147-185. Chicago, IL: University of Chicago Press.

FERnANDEZ, R. (1994) Race, space, and job accessibility: evidence from a plant relocation, Economic Geography, 70, pp. 390-416.

FIELDHOUSE, E. (1999) Ethnic minority unemployment and spatial mismatch: the case of London, Urban Studies, 36, pp. 1569-1596.
Fujita, M. and Thisse, J.-F. (2002) Economics of Agglomeration. Cambridge: Cambridge University Press.

Fujita, M., Thisse, J.-F. and Zenou, Y. (1997) On the endogenous formation of secondary employment centers in a city, Journal of Urban Economics, 41, pp. 337-357.

GALSTER, G. (1990) White flight from racially integrated neighbourhoods in the 1970s: the Cleveland experience, Urban Studies, 27, pp. 385-399.

Galster, G. (2000) Identifying neighborhood thresholds: an empirical exploration, Housing Policy Debate, 11, pp. 701-732.

Garreau, J. (1991) Edge City: Life on the New Frontier. New York: Doubleday.

Giuliano, G. and Small, K. (1991) Subcenters in the Los Angeles region, Regional Science and Urban Economics, 21, pp. 163-182.

Glaeser, E. and Kahn, M. (2001) Decentralized employment and the transformation of the American city, Brookings-Wharton Papers on Urban Affairs, 2, pp. 1-63.

GLAESER, E. and VIDGOR, J. (2001) Racial segregation in the 2000 census: promising news. Survey Series, The Brookings Institution, Washington, DC.

Glaeser, E., Hanushek, E. and Quigley, J. (2004) Opportunities, race, and urban location: the influence of John Kain, Journal of Urban Economics, 56, pp. 70-79.

Gobillon, L. and Selod, H. (2007) The effect of segregation and spatial mismatch on unemployment: evidence from France. CEPR Discussion Paper no. 6198.

Gobillon, L., Magnac, T. and Selod, H. (2007) The effect of location on finding a job in the Paris region. CEPR Discussion Paper no. 6199.

Henderson, V. and Mitra, A. (1996) The new urban landscape: developers and edge cities, Regional Science and Urban Economics, 26, pp. 613-643.

HILlier, A. (2003) Spatial analysis of historical redlining: a methodological exploration, Journal of Housing Research, 14, pp. 137-167.

Holzer, H. (1991) The spatial mismatch hypothesis: what has the evidence shown?, Urban Studies, 28, pp. 105-122.

Holzer, H. and Ihlanfeldt, K. (1998) Customer discrimination and employment outcomes for minority workers, Quarterly Journal of Economics, 113, pp. 835-867.

Holzer, H. and Reaser, J. (2000) Black applicants, Black employees, and urban labor market policy, Journal of Urban Economics, 48, pp. 365-387.

Holzer, H., Ihlanfeldt, K. and Sjoquist, D. (1998) Work search and travel among White 
and Black youth, Journal of Urban Economics, 35 , pp. 320-345.

Holzer, H., Quigley, J. and Raphael, S. (2003) Public transit and the spatial distribution of minority employment: evidence from a natural experiment, Journal of Policy Analysis and Management, 22, pp. 415-442.

Houston, D. (2001) Testing the spatial mismatch hypothesis in the United Kingdom using evidence from firm relocations, European Research in Regional Science, 11, pp. 134-151.

Houston, D. (2005a) Employability, skills mismatch and spatial mismatch in metropolitan labour markets, Urban Studies, 42, pp. 221243.

Houston, D. (2005b) Methods to test the spatial mismatch hypothesis, Economic Geography, 81, pp. 407-434.

Hugues, M. (1995) A mobility strategy for improving opportunity, Housing Policy Debate, 6, pp. $271-297$.

ICELAND, J. and HARRIS, D. (1998) Why work disappears: neighborhood racial composition and employers' relocation. Working Paper No. 1, Joint Center for Poverty Research, Northwestern University/University of Chicago.

IHLANFELDT, K. (1993) Intra-urban job accessibility and Hispanic youth employment rates, Journal of Urban Economics, 33, pp. 254-271.

IHLANFELDT, K. (1997) Information on the spatial distribution of job opportunities within metropolitan areas, Journal of Urban Economics, 41, pp. 218-242.

IHLANFELDT, K. (2006) A primer on spatial mismatch within urban labor markets, in: R. J. Arnott and D. P. McMillen (Eds) $A$ Companion to Urban Economics, pp. 404417. Oxford: Blackwell Publishing.

Ihlanfeldt, K. and SCAFidi, B. (2002) Black self-segregation as a cause of housing segregation: evidence from the multi-city study of urban inequality, Journal of Urban Economics, 51, pp. 366-390.

IhlanfeldT, K. and Sjoquist, D. (1990) Job accessibility and racial differences in youth employment rates, American Economic Review, 80, pp. 267-275.

Ihlanfeldt, K. and Sjoquist, D. (1998) The spatial mismatch hypothesis: a review of recent studies and their implications for welfare reform, Housing Policy Debate, 9, pp. 849-892.

IHLANFELDT, K. and YounG, M. (1994) Intrametropolitan variation in wage rates: the case of Atlanta fast-food restaurant workers, Review of Economics and Statistics, 76, pp. 425-433.

Ihlanfeldt, K. and Young, M. (1996) The spatial distribution of Black employment between the central city and the suburbs, Economic Inquiry, 34, pp. 693-707.
IMMERGLUCK, D. (1998) Job proximity and the urban employment problem: do suitable nearby jobs improve neighbourhood employment rates?, Urban Studies, 35, pp. 7-23.

JeNCKS, C. and MAYER, S. (1990) Residential segregation, job proximity, and Black job opportunities, in: L. E. LYNN and M. G. H. MCGEARY (Eds) Inner-city Poverty in the United States, pp. 187-222. Washington, DC: National Academy Press.

KAIN, J. (1968) Housing segregation, negro employment, and metropolitan decentralization, Quarterly Journal of Economics, 82, pp. 175197.

KAIN, J. (1992) The spatial mismatch hypothesis: three decades later, Housing Policy Debate, 3, pp. 371-460.

KAIN, J. (2004) A pioneer's perspective on the spatial mismatch literature, Urban Studies, 41, pp. 7-32.

KASARDA, J. (1985) Urban change and minority opportunities, in: P. Peterson (Ed.) The New Urban Reality, pp. 33-67. Washington, DC: Brookings Institution.

KASARDA, J. (1988) Jobs, migration, and emerging urban mismatches, in: M. McGeARY and L. LYNN (Eds) Urban Change and Poverty, pp. 148-188. Washington, DC: National Academy Press.

KASARDA, J. (1989) Urban industrial transition and the underclass, Annals of the American Academy of Political Science, 501, pp. 26-47.

Katz, L., Kling, J. and Liebman, J. (2001) Moving to opportunity in Boston: early results of a randomized mobility experiment, Quarterly Journal of Economics, 116(2), pp. 607-654.

Kawabata, M. (2003) Job access and employment among low-skilled autoless workers in US metropolitan areas, Environment and Planning $A, 35$, pp. 1651-1668.

Krovi, R. and Barnes, C. (2000) Work-related travel patterns of people of color, in: Travel Patterns of People of Color, ch. 3. Report prepared by Battelle for the US Department of Transportation, Washington, DC.

LADD, H. (1998) Evidence on discrimination in mortgage lending, Journal of Economic Perspectives, 12, pp. 41-62.

LAdD, H. and Ludwig, J. (1997) Federal housing assistance, residential relocation, and educational opportunities: evidence from Baltimore, American Economic Review, 87, pp. 272-277.

LogAn, J. (2001) The new ethnic enclaves in America's suburbs. Report, Lewis Mumford Center for Comparative Urban and Regional Research, University of Albany, New York.

MARTIN, R. (1997) Job decentralization with suburban housing discrimination: an urban 
equilibrium model of spatial mismatch, Journal of Housing Economics, 6, pp. 293-317.

Martin, R. (2001a) The adjustment of Black residents to metropolitan employment shifts: how persistent is spatial mismatch?, Journal of Urban Economics, 50, pp. 52-76.

Martin, R. (2001b) Spatial mismatch and costly suburban commutes: can commuting subsidies help?, Urban Studies, 38, pp. 1305-1318.

Martin, R. (2004) Can Black workers escape spatial mismatch? Employment shifts, population shifts, and Black unemployment in American cities, Journal of Urban Economics, 55, pp. 179-194.

Mauer, D. and OtT, S. (1999) On the optimal structure of government subsidies for enterprise zones and other locational development programs, Journal of Urban Economics, 45, pp. 421-450.

McGuCKIN, N. (2000) Work, automobility, and commuting, in: Travel Patterns of People of Color, ch. 4. Report prepared by Battelle for the US Department of Transportation, Washington, DC.

McMillen, D. P. and McDonald, J. (1998) Suburban subcenters and employment density in metropolitan Chicago, Journal of Urban Economics, 43, pp. 157-180.

Mendenhall, R., Deluca, S. and Duncan, G. (2006) Neighborhood resources, racial segregation, and economic mobility: results from the Gautreaux program, Social Science Research, 36, pp. 892-923.

Mieszkowski, P. and Mills, E. (1993) The causes of metropolitan suburbanization, Journal of Economic Perspectives, 7, pp. 135-147.

Mills, E. and Lubuele, S. (1997) Inner cities, Journal of Economic Literature, 35, pp. 727-756.

Mortensen, D. and Pissarides, C. (1999) New developments in models of search in the labor market, in: D. CARD and O. Ashenfelter (Eds) Handbook of Labor Economics, pp. 2567-2627. Amsterdam: Elsevier Science.

Mortensen, D. and Vishwanath, T. (1994) Personal contacts and earnings: it is who you know!, Labour Economics, 1, pp. 187-201.

National Advisory Commission on Civil DisORDERS (1968) Report of the National Advisory Commission on Civil Disorders (Kerner Commission Report). Washington: US Government Printing Office.

ONDRICH, J., Ross, S. and Yinger, J. (2000) How common is housing discrimination? Improving on traditional measures, Journal of Urban Economics, 47(3), pp. 470-500.

ONDRICH, J., Ross, S. and Yinger, J. (2001) 'Now you see it, now you don't': why do real estate agents withold available houses from black customers? Working Paper No. 2001-01, Department of Economics, University of Connecticut.

Ong, P. and Blumenberg, E. (1998) Job access, commute and travel burden among welfare recipients, Urban Studies, 31, pp. 77-93.

ONG, P. and Miller, D. (2005) Spatial and transportation mismatch in Los Angeles, Journal of Planning Education and Research, 25, pp. 43-56.

Ortega, J. (2000) Pareto-improving immigration in an economy with equilibrium unemployment, Economic Journal, 110, pp. 92-112.

PAPKE, L. (1994) Tax policy and urban development: evidence from the Indiana enterprise zone program, Journal of Public Economics, 54, pp. 37-49.

PARKS, V. (2004) Access to work: the effects of spatial and social accessibility on unemployment for native-born Black and immigrant women in Los Angeles, Economic Geography, 80, pp. $141-172$.

PAtACChini, E. and Zenou, Y. (2005) Spatial mismatch, transport mode and search decisions in England, Journal of Urban Economics, 58, pp. 62-90.

Patacchini, E. and Zenou, Y. (2006) Search activities, cost of living, and local labor markets, Regional Science and Urban Economics, 36, pp. 227-248.

Phelps, E. (1972) The statistical theory of racism and sexism, American Economic Review, 62, pp. 659-661.

PISSARIDES, C. (2000) Equilibrium Unemployment Theory, 2nd edn. Cambridge, MA: MIT Press.

Preston, V. and McLafferty, S. (1999) Spatial mismatch research in the 1990s: progress and potential, Papers in Regional Science, 78, pp. 387-402.

Pugh, M. (1998) Barriers to work: the spatial divide between jobs and welfare recipients in metropolitan areas. Discussion Paper, Center on Urban and Metropolitan Policy, The Brookings Institution, Washington, DC.

RAPHAEL, S. (1998) The spatial mismatch hypothesis and Black youth joblessness: evidence from the San Francisco Bay area, Journal of Urban Economics, 43, pp. 79-111.

RAPHAEl, S. and Rice, L. (2002) Car ownership, employment, and earnings, Journal of Urban Economics, 52, pp. 109-130.

Raphael, S. and Stoll, M. (2001) Can boosting minority car-ownership rates narrow interracial employment gaps?, Brookings-Wharton Papers on Urban Economic Affairs, 2, pp. 99145.

Raphael, S. and Stoll, M. (2002) Modest progress: the narrowing spatial mismatch between Blacks and jobs in the 1990s. The Brookings Institution, Washington, DC. 
Raphael, S., Stoll, M. and Holzer, H. (2000) Are suburban firms more likely to discriminate against African-Americans?, Journal of Urban Economics, 48, pp. 485-508.

Rogers, C. (1997) Job search and unemployment duration: implications for the spatial mismatch hypothesis, Journal of Urban Economics, 42, pp. 109-132.

Rose-ACKerman, S. (1975) Racism and urban structure, Journal of Urban Economics, 2, pp. 85-103.

Rosenbaum, J. (1991) Black pioneers: do their moves to the suburbs increase economic opportunity for mothers and children?, Housing Policy Debate, 2(4), pp. 1179-1213.

Rosenbaum, J. (1995) Changing the geography of opportunity by expanding residential choice: lessons from the Gautreaux program, Housing Policy Debate, 6, pp. 231-269.

Ross, S. (2005) The continuing practice and impact of discrimination. Working Paper No. 2005-19, Department of Economics, University of Connecticut.

Ross, S. and Tootell, G. (2004) Redlining, the community reinvestment act, and private mortgage insurance, Journal of Urban Economics, 55, pp. 278-297.

Schelling, T. (1969) Models of segregation, American Economic Review Papers and Proceedings, 59, pp. 488-493.

Selod, H. and Zenou, Y. (2006) City structure, job search, and labor discrimination: theory and policy implications, Economic Journal, 116, pp. 1057-1087.

Shapiro, C. and Stiglitz, J. (1984) Equilibrium unemployment as a worker discipline device, American Economic Review, 74, pp. 433-444.

SHEN, Q. (2001) A spatial analysis of job openings and access in a US metropolitan area, Journal of the American Planning Association, 67, pp. 5368.

Smith, T. and Zenou, Y. (1997) Dual labor markets, urban unemployment and multicentric cities, Journal of Economic Theory, 76, pp. 185-214.

Smith, T. and Zenou, Y. (2003) Spatial mismatch, search effort and urban spatial structure, Journal of Urban Economics, 54, pp. 129-156.

South, S. and Crowder, K. (1997) Residential mobility between cities and suburbs: race, suburbanization, and back-to-the-city moves, Demography, 34, pp. 525-538.

SQuires, G. (1996) Closing the racial gap? Mortgage lending and segregation in Milwaukee suburbs. Study prepared for the Fair Lending Coalition, Institute for Wisconsin's Future, July.

Stanback, T. (1991) The New Suburbanization. Boulder, CO: Westview Press.
Steinnes, D. (1977) Causality and intra-urban location, Journal of Urban Economics, 4, pp. 69-79.

Stoll, M. (1998) When jobs move, do Blacks and Latino men lose? The effect of growth in job decentralisation on young men's jobless incidence and duration, Urban Studies, 35, pp. 2221-2239.

Stoll, M. (1999) Spatial job search, spatial mismatch, and the employment and wages of racial and ethnic groups in Los Angeles, Journal of Urban Economics, 46, pp. 129-155.

STOLL, M. (2005) Geographical skills mismatch, job search and race, Urban Studies, 42, pp. 695-717.

Stoll, M. and Raphael, S. (2000) Racial differences in spatial job search patterns: exploring the causes and consequences, Economic Geography, pp. 201-223.

Stoll, M., Holzer, H. and Ihlanfeldt, K. (2000) Within cities and suburbs: racial residential concentration and the spatial distribution of employment opportunities across submetropolitan areas, Journal of Policy Analysis and Management, 19, pp. 207-231.

TAYLOR, B. and ONG, P. (1995) Spatial mismatch or automobile mismatch? An examination of race, residence and commuting in US metropolitan areas, Urban Studies, 32, pp. $1453-1473$.

Thurston, L. and Yezer, A. (1994) Causality in the suburbanization of population and employment, Journal of Urban Economics, 35, pp. $105-118$.

Tootell, G. (1996) Redlining in Boston: do mortgage lenders discriminate against neighborhoods?, Quarterly Journal of Economics, 111, pp. 1049-1079.

TURNER, M. (1998) Moving out of poverty: expanding mobility and choice through tenantbased assistance, Housing Policy Debate, 9, pp. 373-394.

TURNER, S. (1997) Barriers to a better break: employer discrimination and spatial mismatch in metropolitan Detroit, Journal of Urban Affairs, 19, pp. 123-141.

US Bureau of the Census (1997) Current Population Survey. Washington, DC: US Government Printing Office.

US Department OF Housing AND URBAN Development (1998) The State of the Cities: 1998. Washington, DC: US Government Printing Office.

Wasmer, E. and Zenou, Y. (2002) Does citystructure affect job search and welfare?, Journal of Urban Economics, 51, pp. 515-541.

Wasmer, E. and Zenou, Y. (2006) Equilibrium search unemployment with explicit spatial frictions, Labour Economics, 13, pp. 143-165. 
WeinBerg, B. (2000) Black residential centralization and the spatial mismatch hypothesis, Journal of Urban Economics, 48, pp. 110-134.

WEINBERG, B. (2004) Testing the spatial mismatch hypothesis using inter-city variations in industrial composition, Regional Science and Urban Economics, 34, pp. 505-532.

WHEELER, L. (1993) A review of the spatial mismatch hypothesis: its impact on the current plight of the central city in the United States. Occasional Paper No. 137, Metropolitan Studies Program, Maxwell School of Citizenship and Public Affairs, Syracuse University.

White, M. (1999) Urban areas with decentralized employment: theory and empirical work, in: P. Cheshire and E. Mills (Eds) Handbook of Regional and Urban Economics, pp. 13751412. Amsterdam: North-Holland.

Wilson, J. (1987) The Truly Disadvantaged: The Inner City, the Underclass, and Public Policy. Chicago, IL: University of Chicago Press.

Wilson, J. (1996) When Work Disappears: The World of the New Urban Poor. New York: Alfred A. Knopf.

YINGER, J. (1976) Racial prejudice and racial residential segregation in an urban model, Journal of Urban Economics, 3, pp. 383-396.

YINGER, J. (1986) Measuring racial discrimination with fair housing audits, American Economic Review, 76, pp. 881-893.

YINGER, J. (1996) Discrimination in mortgage lending: a literature review, in: J. GoERING and R. WIEnK (Eds) Mortgage Lending, Racial Discrimination and Federal Policy, pp. 29-74. Washington, DC: Urban Institute Press.

ZAX, J. and KAIN, J. (1996) Moving to the suburbs: do relocating companies leave their Black employees behind?, Journal of Labor Economics, 14, pp. 472-504.

ZENOU, Y. (2000) Urban unemployment, agglomeration and transportation policies, Journal of Public Economics, 77, pp. 97-133.

ZENOU, Y. (2002) How do firms redline workers?, Journal of Urban Economics, 52, pp. 391-408.

ZeNou, Y. (2006) Efficiency wages and unemployment in cities: the case of high-relocation costs, Regional Science and Urban Economics, 36, pp. 49-71.

ZenOu, Y. and Boccard, N. (2000) Labor discrimination and redlining in cities, Journal of Urban Economics, 48, pp. 260-285. 